Membership. The Membership Committee staffed a highly successful booth at Annual Conference in New Orleans. They distributed materials, presented a video of Cincinnati, and held a drawing for a video prepared by the Arizona State University Libraries.

Support elected and appointed leaders. Our second annual orientation meeting for new committee chairs and section heads was successful. Information was offered by ACRL leaders and staff, guides were handed out, and there was time for some discussion.

The ACRL Annual Report appeared in a beautiful new format. We hope that it will encourage units to submit reports for inclusion next year.
Cooperate with other ALA units. Staff and key leaders are preparing for three important events this fall: the third annual divisional leadership program, where the presidents-elect of all 11 divisions convene to learn about ALA, meet one another, and work with the divisional staffs; the first joint meeting of divisional executive committees, where common issues, such as the revision of the Operating Agreement can be discussed, as well as individual agenda items; and an "Operating Agreement Summit," where each division will have one representative as negotiator with members of the ALA COPES Committee in drafting a new set of policies for ALA in relation to the divisions. - JoAn S. Segal, ACRL Executive Director.

\title{
ACRL actions, July 1988
}

\section{Highlights of the Annual Conference meetings of the ACRL Board of Directors.}

$\mathbf{T}$ he Board of Directors of the Association of College and Research Libraries met twice during the ALA Annual Conference in New Orleans: on July 9, 1988, and July 12, 1988.

\section{Bibliographic instruction}

The Board approved a "Model Statement of Objectives for Academic Bibliographic Instruction" developed by a Bibliographic Instruction Section task force, with the provision that the authors clarify some language in a section dealing with unrecorded information sources (see draft in $C \& R L$ News, May 1987). The revised statement will appear in a future issue of $C \& R L$ News.

\section{Budget and finance}

The Board approved a schedule for the development of the ACRL Financial Plan. There will be an open hearing on the plan next Midwinter, and a final version will be approved by the Board at Annual Conference in Dallas in 1989.

The Board also approved two revisions to the
ACRL Fiscal Policy Manual-one on travel funds and the other on conference expenses.

The Board approved the 1989 ACRL budget with revenues of $\$ 1,111,875$ and expenses of $\$ 1,111,080$.

\section{Bylaws}

The Board approved a change in the ACRL Bylaws that would allow sections to designate their representatives to the Activity Sections Council. The representatives would be two of the three following officers: chair, vice-chair/chair-elect, or past chair.

The Board approved sample bylaws for use by ACRL sections in need of information on the writing or revision of section bylaws.

\section{Discussion groups}

The board approved petitions for the creation of two new discussion groups: the Journal Costs in Academic Libraries Discussion Group and the Popular Culture and Libraries Discussion Group. 


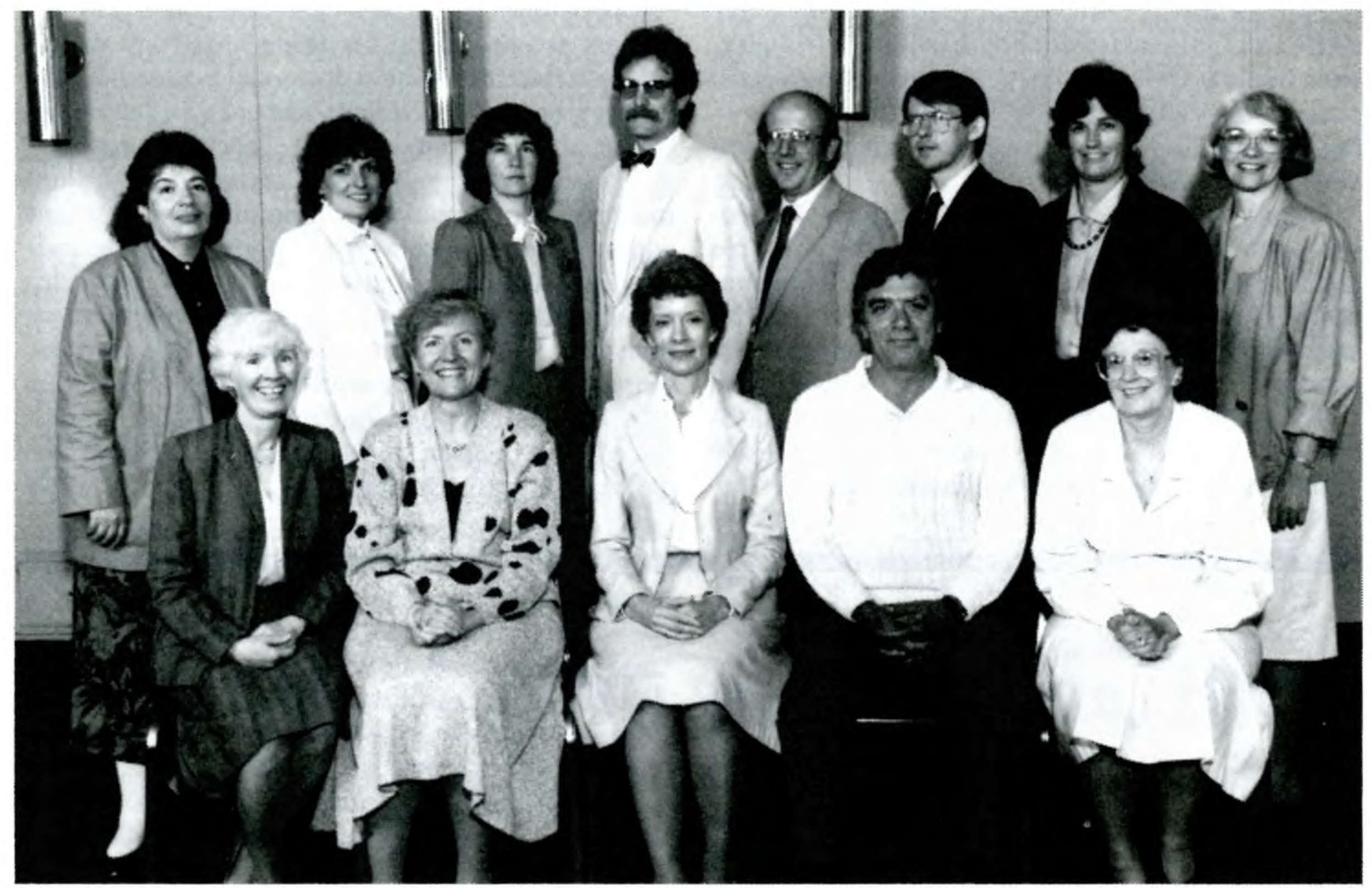

ACRL Board, 1987-88. Back row: Rochelle Sager, Anne Beaubien, Elizabeth Salzer, Lee Hisle, Peter Malanchuk, Larry Hardesty, Mary Sue Ferrell, Patricia Wand. Front row: JoAn Segal, Hannelore Rader, Joanne Euster, Joseph Boissé, Anne Commerton. Not present: Thomas Kirk, Melvin George, Bob Carmack.

\section{Fund raising}

The Board received the final report of the Task Force on Fund Raising, discharged the Task Force with thanks, and referred the report to the Planning Committee for its review and recommendations. The report recommends the creation of a discussion group on fund raising, the publication of articles on development and fund raising, and action on the ALA fund raising clearinghouse proposal developed in cooperation with LAMA.

\section{Microfiche conversion}

The Board endorsed the resolution on the GPO microfiche conversion program. The resolution supports efforts by the U.S. Government Printing Office to develop specifications in future contracts that ensure high quality production and timely distribution of microfiche products.

\section{Rare Books \& Manuscripts Librarianship}

The Board approved a policies and procedures document for $R B M L$ and approved the appointment of Alice Schreyer as editor of the journal.

\section{School library media specialists}

The Board discussed a draft of "Professional Competencies for Entry Level School Library Media Specialists," prepared by the ALA/AASL/N-
CATE Guidelines Task Force. General support for the document was expressed but the Board clarified that they were taking no implied action on the issue of an MLS degree requirement.

\section{Sections}

The Rare Books and Manuscripts Section was congratulated on the occasion of its 30th anniversary (see box, p.495).

\section{Statistics}

Upon the recommendation of the Academic Library Statistics Committee, the Board voted: 1) not to expand ACRL's statistical survey to all college and university libraries because of costs and level of interest in nationwide statistics gathering; 2) to continue to survey the non-ARL university libraries and return to using the ARL form; 3) to encourage the academic library community to complete and return the IPEDS surveys (see pp. 521-22); and 4) to encourage the federal government to gather library data every other year.

\section{Strategic planning}

The Board established their top priority for the next two years. It will be Goal III of the ACRL Strategic Plan: "to promote and speak for the interests of academic and research librarianship." Specific focuses will be on Subgoal A, which deals with 


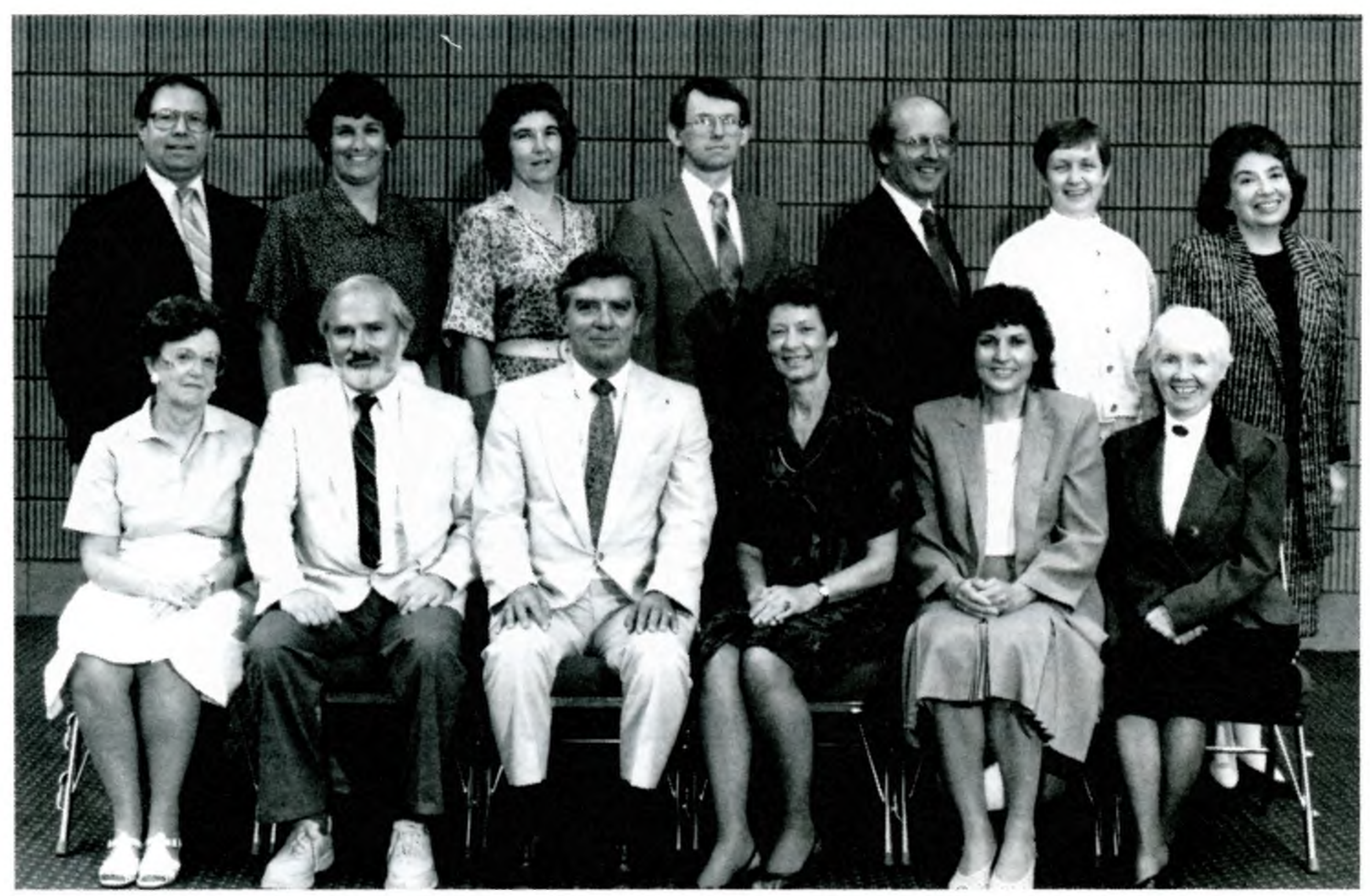

ACRL Board, 1988-89. Back row: Thomas Kirk, Mary Sue Ferrell, Elizabeth Salzer, Larry Hardesty, Peter Malanchuk, Linda Piele, Rochelle Sager. Front row: Anne Commerton, William A. Moffett, Joseph A. Boissé, Joanne Euster, Anne Beaubien, JoAn S. Segal. Not present: Melvin George.

improving relationships with non-library professionals and organizations, and on Subgoal C, which deals with recruitment and retention of outstanding persons to the field of academic and research librarianship.

\section{Task forces}

The Board extended the terms of the Task Force on Library Access and the Task Force on Librarians as Instructors until the 1989 Annual Conference. The Library Access Task Force is developing guidelines for access policy statements, and the Librarians as Instructors Task Force is surveying academic administrators on their role in support of librarians in user education. Their survey information will be used in preparing a guideline statement.

Upon a recommendation from incoming ACRL President Joe Boissé, the Board established four new task forces: Paraprofessionals in Academic Libraries; Small College Assessment Program; Recruitment of Underrepresented Minorities; and Library School Curriculum.

The Board established a task force to explore the possibility of starting a service corps of retired librarians. Evan Ira Farber, who proposed the idea, was named chair of the task force.

The Board established a task force to oversee the writing of a grant proposal to study sources of revenue in academic libraries.
Another task force was established to explore non-dues sources of revenue for ACRL.

\section{RBMS is 30 years old}

The Rare Books and Manuscripts Section became a separate section of ACRL during the 1958 Midwinter Meeting. The 30th anniversary of the section was marked during the 29th RBMS Preconference, "Libraries and Museums: Leaves from Each Other's Books," held in New Orleans, July 5-8, 1988. The opening reception at the Historic New Orleans Collection doubled as a birthday party, with a bookshaped birthday cake and toasts offered by RBMS officers and founders.

Robert Vosper, university librarian and professor emeritus at the University of California, Los Angeles, spoke briefly prior to cutting the cake. Vosper, who served as ACRL President in 1955-56 and as ALA President in 1965-66, chaired the Special Committee to Study Section Status for the ACRL Rare Books Committee, and he forwarded the proposal recommending section status to ACRL.

Alice Schreyer, assistant director of libraries for special collections at the University of Delaware and chair of RBMS, read from letters of congratulation written by founders and former officers not present at the preconference. 